\title{
Can the Nitrogen and Silicon Increase the Productivity and Yield in Rice Crops in the Rainfed Environment?
}

\author{
Evandro Marcos Biesdorf ${ }^{1}$, Alexandre Maniçoba da Rosa Ferraz Jardim² ${ }^{2}$, Elivelton Maciel Biesdorf ${ }^{1}$, \\ Angélica Fátima de Barros ${ }^{3}$, Charles de Araújo ${ }^{1} \&$ Leonardo Duarte Pimentel ${ }^{3}$ \\ ${ }^{1}$ Federal Institute of Education, Science and Technology of Mato Grosso, Campo Verde, Brazil \\ ${ }^{2}$ Federal Rural University of Pernambuco, Recife, Brazil \\ ${ }^{3}$ Federal University of Viçosa, Viçosa, Brazil \\ Correspondence: Evandro Marcos Biesdorf, Federal Institute of Education, Science and Technology of Mato \\ Grosso, Campo Verde, SGAN 906, Módulo B, Bloco A, Ap 119, CEP 70790-060, Brasília, DF, Brazil. Tel: \\ 55-61-99801-6959. E-mail: evandromarcospva@hotmail.com
}

Received: August 11, 2019

doi:10.5539/jas.v11n18p117
Accepted: September 28, 2019

Online Published: November 15, 2019

\begin{abstract}
There is much doubt as to whether, in fact, the combination of nitrogen and silicate fertilization can increase yield and post-harvest yield in rainfed rice. The objective of this study was to investigate the effect of silicate and nitrogen fertilization on the development, quality, yield and post-harvest yield of rice cultivated in the rainfed environment. A field experiment was carried out in the 2014/2015 harvest in a $4 \times 4$ randomized block design with four replications. The first factor corresponded to the nitrogen doses $\left(0 ; 50 ; 100\right.$ and $200 \mathrm{~kg} \mathrm{ha}^{-1}$ of N), in the form of urea, and the second factor at silicon doses $\left(0 ; 7.5 ; 15\right.$ and $\left.30 \mathrm{~kg} \mathrm{ha}^{-1} \mathrm{Si}\right)$, in the form of calcium silicate. Si affected the chlorophyll content at 45 days after sowing (DAS) suggesting being important in floral differentiation. The increase in $\mathrm{N}$ doses caused higher levels of chlorophyll in rice leaves at 55, 65 and 85 DAS, regardless of whether they supplied Si. Plant height, number of tillers, weight of one thousand seeds, total grain yield and of whole grains were not influenced by the Si supply. However, Si doses reduced the yield of broken grains, thus reducing postharvest losses and, consequently, improving grain quality in the beneficiation process.
\end{abstract}

Keywords: Oryza sativa L., SPAD, silicate, nitrogen, post-harvest

\section{Introduction}

Rice (Oryza sativa L.) cultivated in the rainfed environment has always been predominantly associated with cultivation in the opening of the area, in soils, generally of low natural fertility and without a history of agricultural exploitation (Sun et al., 2019). However, there is currently an increase in the number of producers interested in cultivating this grass as an alternative to the production system most practiced or exercised in the Brazilian Cerrado biome, characterized by intense and technological soybean cultivation in the summer and corn in the fall (Gmach et al., 2018). In these environments, the greatest challenge is the consolidation of the crop, in a sustainable way regarding fertilization, especially in the no-tillage system (Cazetta et al., 2008; Sun et al., 2019).

Nitrogen $(\mathrm{N})$ is the most limiting nutrient in rice production, most exported at harvest and responsible for most of the production cost (Yoneyama et al., 2016). In this context, several efforts are being made to improve the use of this element, especially in conjunction with the application of silicon $(\mathrm{Si})$, aiming to improve productivity, abiotic stresses and rice quality (Ávila et al., 2010; Marxen et al., 2016).

Silicon ( $\mathrm{Si}$ ) is the second most abundant element in the soil (preceded only by oxygen) and is considered a mineral element beneficial to the growth and development of many grass species, such as wheat, barley and rice (Ning et al., 2017). In rice, absorbed silicon is accumulated in the tissues and contributes to increase the photosynthetic rate and the efficiency of water use and reduce the transpiration rate and toxicity to heavy metals (Seebold et al., 2004; Marxen et al., 2016).

Despite this, there are still many doubts about the effect of silicate fertilization on increasing the resistance to grain breakage and, consequently, on the yield of whole grains after the beneficiation process. There are authors who have shown a reduction in the proportion of broken grains (Artigiani et al., 2012), while others did not 
observe effect of Si on the post-harvest yield of rice (Marchezan et al., 2004). Therefore, nitrogen fertilization can alter the availability and deposition of $\mathrm{Si}$ in the rice plant, leading to a decrease in the mechanical resistance to fungi penetration and, consequently, reducing the yield and quality of rice grains (Mauad et al., 2013; Mo et al., 2017), the addition of Si could improve the utilization of the nitrogen supplied to the rice, increasing the yield and quality in the post-harvest of the rice. However, there are no studies on the interaction between $\mathrm{N}$ and Si doses in the rice crop aiming at the post-harvest quality of the grain.

The objective of this study was to investigate the effect of silicate and nitrogen fertilization on the development, quality, yield and post-harvest yield of rice cultivated in the rainfed environment.

\section{Method}

\subsection{Experimental Conditions and Experimental Design}

The experiment was carried out in the municipality of Campo Verde, located in the southern region of the State

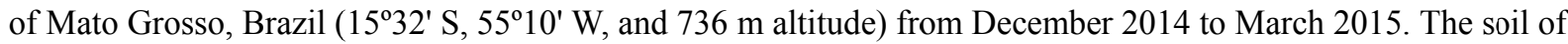
the experimental area was characterized as a dystric ferritic Ferralsoil (WRB), in a closed environment. The climate of the region is type Aw by the classification of Köppen, rainy tropical with dry season in winter and rainy in autumn, with average annual rainfall of 2,000 $\mathrm{mm}$ and average monthly temperature of $22.2{ }^{\circ} \mathrm{C}$ (Figure $1)$.

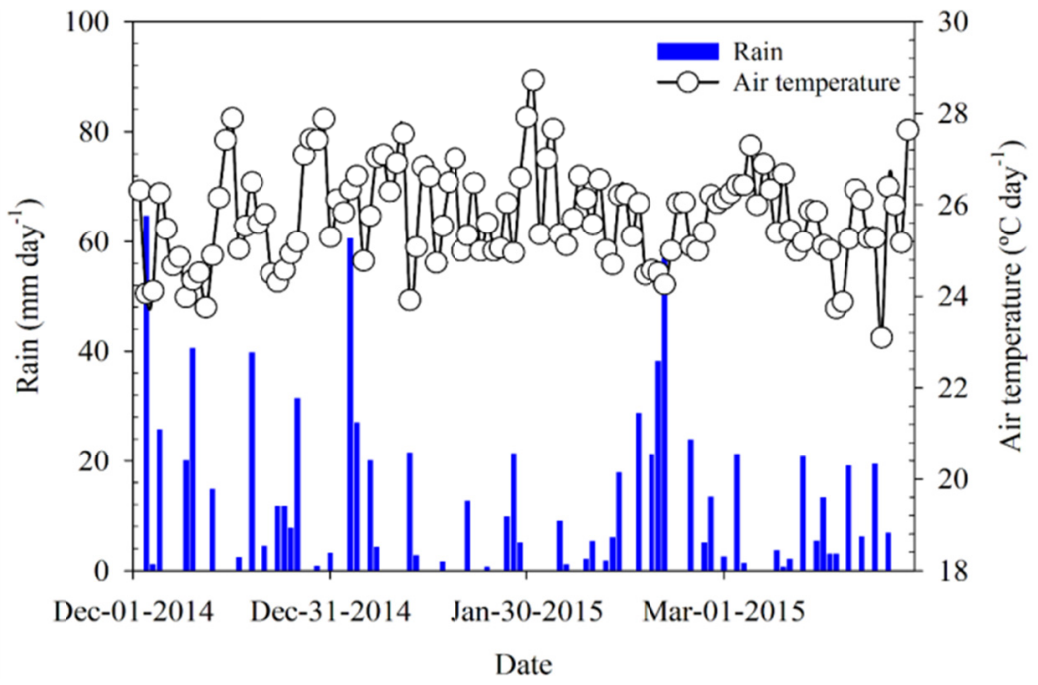

Figure 1. Rain (mm) and air temperature $\left({ }^{\circ} \mathrm{C}\right)$ observed during the experiment in the field. Campo Verde, MT, Brazil season 2014/2015

The meteorological data were monitored throughout the conduction of the experiment. The mean temperature was $25.5{ }^{\circ} \mathrm{C}$, while the total precipitation during the experiment period was $1,207 \mathrm{~mm}$. The months of highest rainfall indexes were December and February, which presented values of $438.3 \mathrm{~mm}$ and $286.4 \mathrm{~mm}$, respectively (Figure 1).

The treatments were arranged in a $4 \times 4$ factorial scheme, in a randomized complete block design, with four replications. Each plot was composed of eight rows of $5.0 \mathrm{~m}$ in length, spaced $0.25 \mathrm{~m}$, totaling $10 \mathrm{~m}^{2}$ of area. The AN Cambará variety was used, using 45 seeds per meter, totalizing a stand of $1,800,000$ plants $\mathrm{ha}^{-1}$. To eliminate the border effect, the four central rows were considered as useful area, $0.5 \mathrm{~m}$ away from the lateral ends, and $1.0 \mathrm{~m}$ from the ends of each planting line.

The first factor corresponded to the doses of $\mathrm{N}\left(0 ; 50 ; 100\right.$ and $\left.200 \mathrm{~kg} \mathrm{ha}^{-1}\right)$, applied as urea cover $(45 \% \mathrm{~N})$ at 30 days after sowing (DAS), and the second factor at $\mathrm{Si}\left(0 ; 75 ; 150\right.$ and $\left.300 \mathrm{~kg} \mathrm{ha}^{-1}\right)$, applied in the planting in the form of calcium silicate $(10 \% \mathrm{Si})$.

Representative soil samples were collected in the 0 to $0.20 \mathrm{~m}$ depth layer, prior to the experiment. The results of the physicochemical analyzes were as follows: $\mathrm{pH}\left(\mathrm{H}_{2} \mathrm{O}\right)=5.7 ; \mathrm{P}=1.4 \mathrm{mg} \mathrm{dm}^{-3} ; \mathrm{K}=33.7 \mathrm{mg} \mathrm{dm}^{-3} ; \mathrm{Ca}+\mathrm{Mg}=$ $0.9 \mathrm{cmol}_{\mathrm{c}} \mathrm{dm}^{-3} ; \mathrm{H}+\mathrm{Al}=1.4 \mathrm{cmol}_{\mathrm{c}} \mathrm{dm}^{-3} ;$ organic matter $=9.7 \mathrm{~g} \mathrm{dm}^{-3} ; \mathrm{V}=41.3 \% ; \mathrm{T}=2.3 \mathrm{cmol}_{\mathrm{c}} \mathrm{dm}^{-3} ;$ clay $^{-1}$ $454.0 \mathrm{~g} \mathrm{~kg}^{-1}$; sand $=504.0 \mathrm{~g} \mathrm{~kg}^{-1}$; silt $=42.0 \mathrm{~g} \mathrm{~kg}^{-1}$. 


\subsection{Sampling and Measurements}

It was performed, prior to the implementation of the experiment, surface grading at 0.3 meters depth. The soil was corrected by the application of limestone (RTNP: 100\%) to raise the base saturation to $60 \%$. At the time of sowing of the rice, fertilization with $200 \mathrm{~kg} \mathrm{ha}^{-1}$ of the NPK formula 0-25-15 was carried out in the planting groove. In the cover, at 30 DAS, fertilization with $60 \mathrm{~kg} \mathrm{ha}^{-1}$ of $\mathrm{K}_{2} \mathrm{O}$, in the form of potassium chloride, was applied in a total area with haul in all plots. Correction and fertilization were done according to the recommendation for the crop (Paula et al., 1999), varying only the doses of $\mathrm{N}$, according to the treatments.

The weed control was applied with oxadiazon herbicides $\left(750 \mathrm{~g}\right.$ i.a. ha $\left.{ }^{-1}\right)$ in pre-emergence and, at 17 days after emergence, bentazon (720 g i.a. $\mathrm{ha}^{-1}$ ) was applied. Diseases and pests did not reach the level of economic damage and therefore no chemical control was necessary.

At 45, 55, 65 and 85 DAS, readings of the chlorophyll content of the newly developed leaf of the main rice tiller were carried out. Readings occurred in the period from 7:00 AM to 9:00 AM with the portable SPAD 502 chlorophyll meter (Minolta Company ${ }^{\circledR}$ ). In each plot, 10 leaves of plants located in the four central rows were randomly sampled, forming an average of each plot. At harvest time, the following characteristics were evaluated: plant height $(\mathrm{PH}, \mathrm{cm})$, obtained by the mean height of ten plants at random in the useful area of each plot, considering the distance between the soil surface and the apex of the panicle; number of tillers per plant (NTP, $\mathrm{n} \mathrm{pl}^{-1}$ ), evaluated by the average of the tillers found in 10 random plants in the useful area of each plot. The shoot dry matter (SDM, Mg ha ${ }^{-1}$ ), after being harvested, was obtained by weighing the plants contained in two linear meters in the useful area of each plot, after the plants were taken to the greenhouse with forced circulation of air at $65{ }^{\circ} \mathrm{C}$ until they reach a constant mass.

The grain yield (GY, Mg ha ${ }^{-1}$ ) (13\% wet basis) was obtained based on the mass of the grains harvested in the plot area. From this mass, the weight of one thousand seeds (TSW, g) the yield of whole grains (WGY, Mg ha ${ }^{-1}$ ) and broken (BGY, $\mathrm{Mg} \mathrm{ha}^{-1}$ ) were obtained. All masses were measured on an analytical precision scale.

For the evaluation of the yield of grains benefited (YGB, $\mathrm{Mg} \mathrm{ha}^{-1}$ ) and percentage yield of grains benefited (PYGB \%), all rice samples were pre-cleaned and dried at $13 \%$ moisture (b.u.) under temperature of $\pm 60{ }^{\circ} \mathrm{C}$. Subsequently, they were benefited in a Suzuki test facility for one minute to remove the peel and grain polishing and for 30 seconds in the "trieur" to separate the whole grains from the broken ones. Grains were harvested 15 days after harvest.

\subsection{Statistical Analysis}

The evaluated characteristics were submitted to the normality and homoscedasticity tests, as well as the analysis of variance (ANOVA) and regression. The regression models were chosen based on the significance of the regression coefficients by the $t$ test at $5 \%$ probability level. The characteristics evaluated at the different stages of development were related to the applied $\mathrm{N}$ and $\mathrm{Si}$ doses. All statistical analyzes were performed in the R (R Core Team, 2015) program.

\section{Results}

\subsection{Effects on Grain Yield and Yield Components}

The $\mathrm{N}$ and $\mathrm{Si}$, individually analyzed, significantly influenced $(\mathrm{p}<0.05)$ the chlorophyll leaf contents evaluated by SPAD at 45 DAS (Table 1). Except for 85 DAS, Si affected chlorophyll content of rice plants when combined to $\mathrm{N}$ rates. On the other hand, at 55, 65 and $85 \mathrm{DAS}$, the $\mathrm{Si}$, individually considered, did not affect significantly the chlorophyll content in the leaf. There was also significant interaction between Si and N at 45, 55 and 65 DAS (Table 1). However, at 55, 65 and 85 DAS, different doses of Si provide the same chlorophyll content (Figures $2 \mathrm{~A}, 2 \mathrm{~B}$, and 3D). 
Table 1. Analysis of variance of SPAD index evaluations at 45, 55, 65 and 85 days after sowing (DAS) of cultivar AN Cambará, harvest 2014/2015. Campo Verde, MT, Brazil 2015

\begin{tabular}{|c|c|c|c|c|}
\hline \multirow{2}{*}{ Treatment } & \multicolumn{4}{|c|}{ DAS } \\
\hline & $45^{(1)}$ & 55 & 65 & 85 \\
\hline & ----------. & ------------- & $\begin{array}{l}\text { alues ---- } \\
S^{(2)}-----\end{array}$ & ----------- \\
\hline Doses of $N$ & $55.03 * *$ & $333.2 * *$ & $318^{* *}$ & $101.7 * *$ \\
\hline Doses of $\mathrm{Si}$ & $7.97 * *$ & $1.51^{\mathrm{ns}}$ & $0.14^{\mathrm{ns}}$ & $4.23^{\mathrm{ns}}$ \\
\hline $\mathrm{N} * \mathrm{Si}$ & $14.53^{* *}$ & $2.93^{*}$ & $2.88^{*}$ & $1.56^{\mathrm{ns}}$ \\
\hline $\mathrm{CV}(\%)$ & 19.05 & 4.7 & 4.69 & 5.17 \\
\hline
\end{tabular}

Note. ${ }^{(1)}$ SPAD evaluations performed at 45, 55, 65 and 85 days after sowing. ${ }^{(2)}$ SPAD units; **, * and ns: significant at $1 \%, 5 \%$ and not significant, respectively, at the t-test.

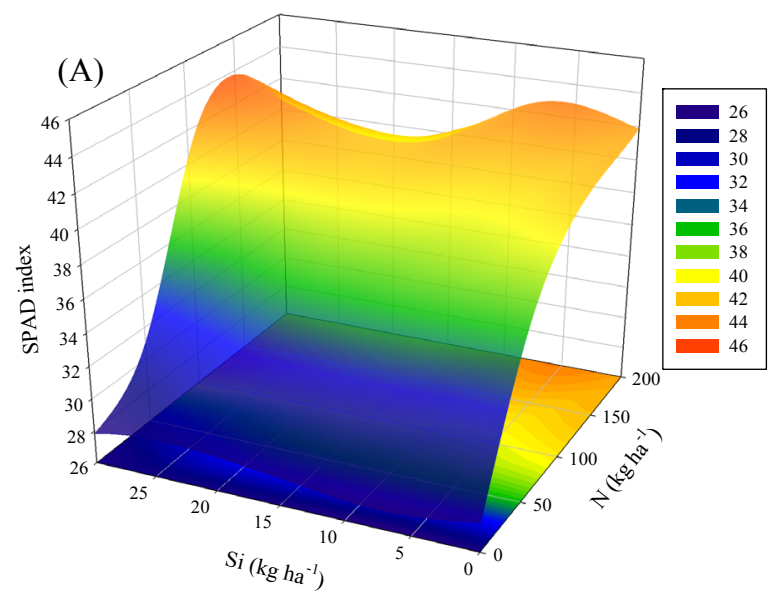

$\mathrm{Z}=28,1221^{* *+0}, 1712 * * \mathrm{x}-0,0005^{* *} \mathrm{x} 2-0,0472 \mathrm{y} ; \mathrm{R}^{2}=0,90 ;$ sig. $=1 \%$

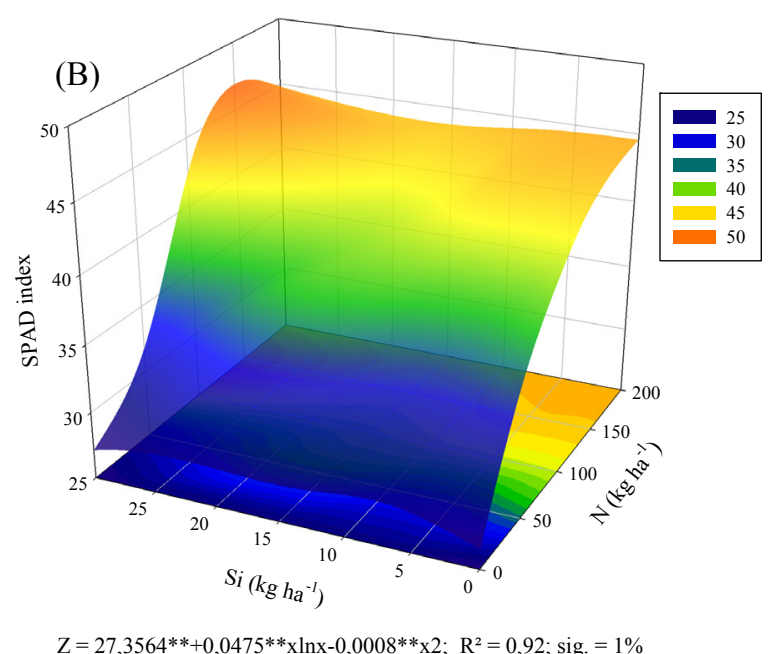

$\mathrm{Z}=27,3564 * *+0,0475^{* *} \mathrm{x} \ln \mathrm{x}-0,0008^{* *} \times 2 ; \mathrm{R}^{2}=0,92 ;$ sig. $=1 \%$

Figure 2. SPAD index collected in the leaf limb of rice plants as a function of the nitrogen $(\mathrm{N})$ and silicon (Si) rates. Graphs A-B represent the collections done at 55 and 65 days after plant germination, respectively. * and **, represent significance (sig.) at the $5 \%$ and $1 \%$ probability levels by the $t$ test, respectively

The increase in the chlorophyll content in the leaf was proportional to the increase of the doses of $\mathrm{N}$ applied (Figures 3A, 3B, 3C and 3D). For the evaluation performed at $45 \mathrm{DAS}$, in those plots where no silicon addition was applied, 7.5 and $15 \mathrm{~kg} \mathrm{ha}^{-1}$ of $\mathrm{Si}$, the maximum levels of chlorophyll were 40.9; 39.6 and 38.7 US, with doses of 200, 100 and $100 \mathrm{~kg} \mathrm{ha}^{-1}$ of $\mathrm{N}$, respectively (Figure 3A). It should be noted that in the combination of $30 \mathrm{~kg} \mathrm{ha}^{-1}$ of Si, in combination with the different doses of $\mathrm{N}$, the behavior of the chlorophyll content in the leaf was different in the proportion that with the increase of the nitrogen doses, there was initially a stabilization of the values obtained for only above $100 \mathrm{~kg} \mathrm{ha}^{-1}$ of $\mathrm{N}$ were verified the increase of these contents in the leaf. 
(A)

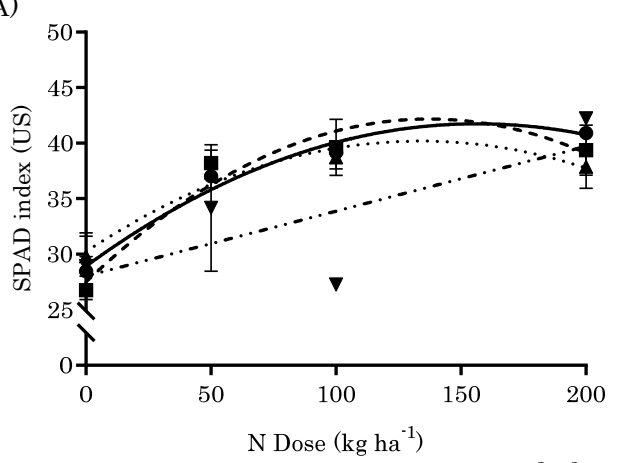

$\rightarrow 0 \mathrm{~kg} \mathrm{ha}{ }^{-1}$ of Si $\mathrm{y}=28.9+0.1639 \mathrm{x}-0.0005 \mathrm{x}^{2} \mathrm{R}^{2}=0.91^{*}$

- - $7.5 \mathrm{~kg}$ ha ${ }^{-1}$ of Si $\mathrm{y}=27.49+0.2137 \mathrm{x} \cdot 0.0007 \mathrm{x}^{2} \mathrm{R}^{2}=0.86^{*}$

.4. $15 \mathrm{~kg} \mathrm{ha}{ }^{-1}$ of $\mathrm{Si} \quad \mathrm{y}=30.21+0.149 \mathrm{x}-0.0005 \mathrm{x}^{2} \mathrm{R}^{2}=0.85^{*}$

-.$\quad 30 \mathrm{~kg} \mathrm{ha}^{-1}$ of Si $\quad \mathrm{y}=30.68 \cdot 0.0520 \times \mathrm{R}^{2}=0.58^{*}$

(C)

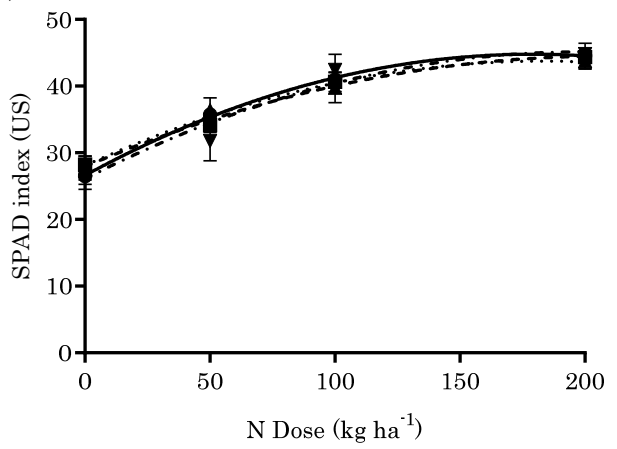

$\rightarrow 0 \mathrm{~kg} \mathrm{ha}{ }^{-1}$ of Si $\quad \mathrm{y}=26.61+0.2032 \mathrm{x} \cdot 0.0005 \mathrm{x}^{2} \mathrm{R}^{2}=0.94^{* *}$

-匹. $7.5 \mathrm{~kg} \mathrm{ha}^{-1}$ of Si $\mathrm{y}=27.92+0.1593 \mathrm{x} \cdot 0.0003 \mathrm{x}^{2} \mathrm{R}^{2}=0.96^{* *}$

.4. $15 \mathrm{~kg} \mathrm{ha}^{-1}$ of Si $\quad \mathrm{y}=28.08+0.1703 \mathrm{x} \cdot 0.0004 \mathrm{x}^{2} \mathrm{R}^{2}=0.93^{* *}$

- $\mathbf{-} \quad 30 \mathrm{~kg} \mathrm{ha}{ }^{-1}$ of Si $\mathrm{y}=26.11+0.1912 \mathrm{x} \cdot 0.0004 \mathrm{x}^{2} \mathrm{R}^{2}=0.88^{*}$
(B)

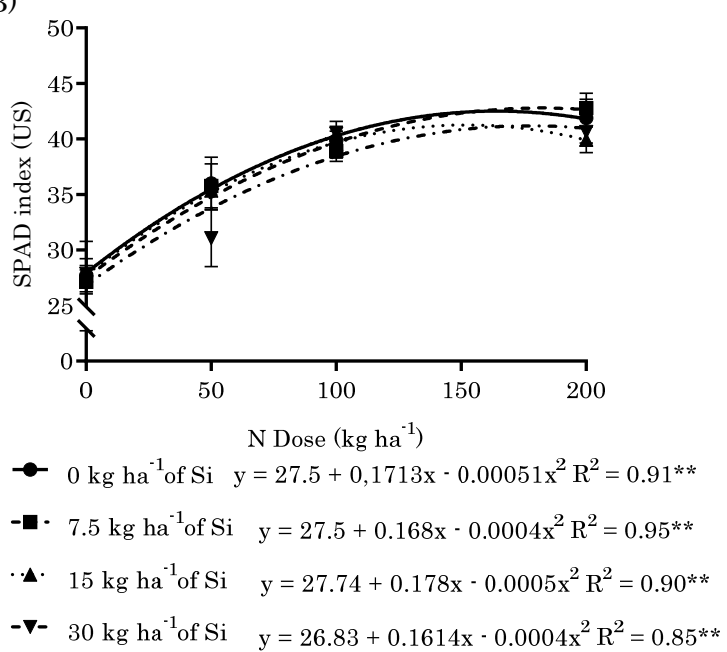

(D)

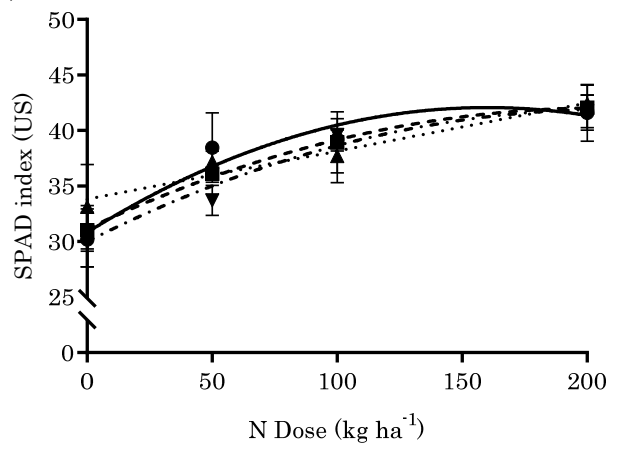

$0 \mathrm{~kg} \mathrm{ha}{ }^{-1}$ of Si $\mathrm{y}=30.81+0.1406 \mathrm{x} \cdot 0.0004 \mathrm{x}^{2} \mathrm{R}^{2}=0.75^{*}$

- $7.5 \mathrm{~kg}$ ha ${ }^{-1}$ of Si $\mathrm{y}=31.14+0.1059 \mathrm{x} \cdot 0.0002 \mathrm{x}^{2} \mathrm{R}^{2}=0.84^{*}$

.. $15 \mathrm{~kg} \mathrm{ha}^{-1}$ of $\mathrm{Si} \quad \mathrm{y}=33.5+0.0556 \mathrm{x} \mathrm{R}^{2}=0.69 \mathrm{~ns}$

- $\mathbf{-}-30 \mathrm{~kg}$ ha ${ }^{-1}$ of Si $\mathrm{y}=29.99+0.1134 \mathrm{x} \cdot 0.0002 \mathrm{x}^{2} \mathrm{R}^{2}=0.85^{*}$

Figure 3. SPAD index of Leaf chlorophyll content (LCC) at 45 (A), 55 (B), 65 (C) and 85 (D) days after sowing of dry rice, as a function of $\mathrm{N}$ and Si doses US: SPAD units. Cultivar AN Cambará. 2014/2015 crop year. Campo Verde, MT, Brazil 2015

There was a significant effect of $\mathrm{N}$ doses for all evaluated characteristics, except for NT, however there was no significant effect of any of the Si doses (Table 2) (Figures 4A, 4B, and 4C). The effect of the interaction between $\mathrm{Si}$ and $\mathrm{N}$ doses was significant only for $\mathrm{PH}$ and $\mathrm{PG}$. The coefficient of variation (\%) was from $5.1(\mathrm{PH})$ to $19.54 \%$ (SDM), indicating good experimental accuracy.

Table 2. Analysis of variance of plant height (PH), number of tillers (NT), shoot dry matter (SDM), grain yield (GY) and weight of one thousand seeds (TSW). Cultivar AN Cambará. 2014/2015 crop year. Campo Verde, MT, Brazil 2015

\begin{tabular}{|c|c|c|c|c|c|}
\hline Treatment & $\mathrm{PH}$ & NT & SDM & GY & TSW \\
\hline & $\mathrm{cm}$ & - & |------ & $\mathrm{ha}^{-1}$------------- & $\mathrm{g}$ \\
\hline Doses of $\mathrm{N}$ & $18.11^{* *}$ & $3.63^{\mathrm{ns}}$ & $6.04 *$ & $16.39 * *$ & $11.22 * *$ \\
\hline Doses of $\mathrm{Si}$ & $1.18^{\mathrm{ns}}$ & $3.45^{\mathrm{ns}}$ & $1.15^{\mathrm{ns}}$ & $3.14^{\mathrm{ns}}$ & $0.70^{\mathrm{ns}}$ \\
\hline $\mathrm{N}^{*} \mathrm{Si}$ & $2.61 *$ & $2.11^{\mathrm{ns}}$ & $1.58^{\mathrm{ns}}$ & $2.33 *$ & $1.13^{\mathrm{ns}}$ \\
\hline CV $(\%)$ & 5.1 & 15.76 & 19.54 & 15.26 & 6.28 \\
\hline
\end{tabular}

Note. ${ }^{* *}, *$ and ns: significant at $1 \%, 5 \%$ and not significant, respectively. 

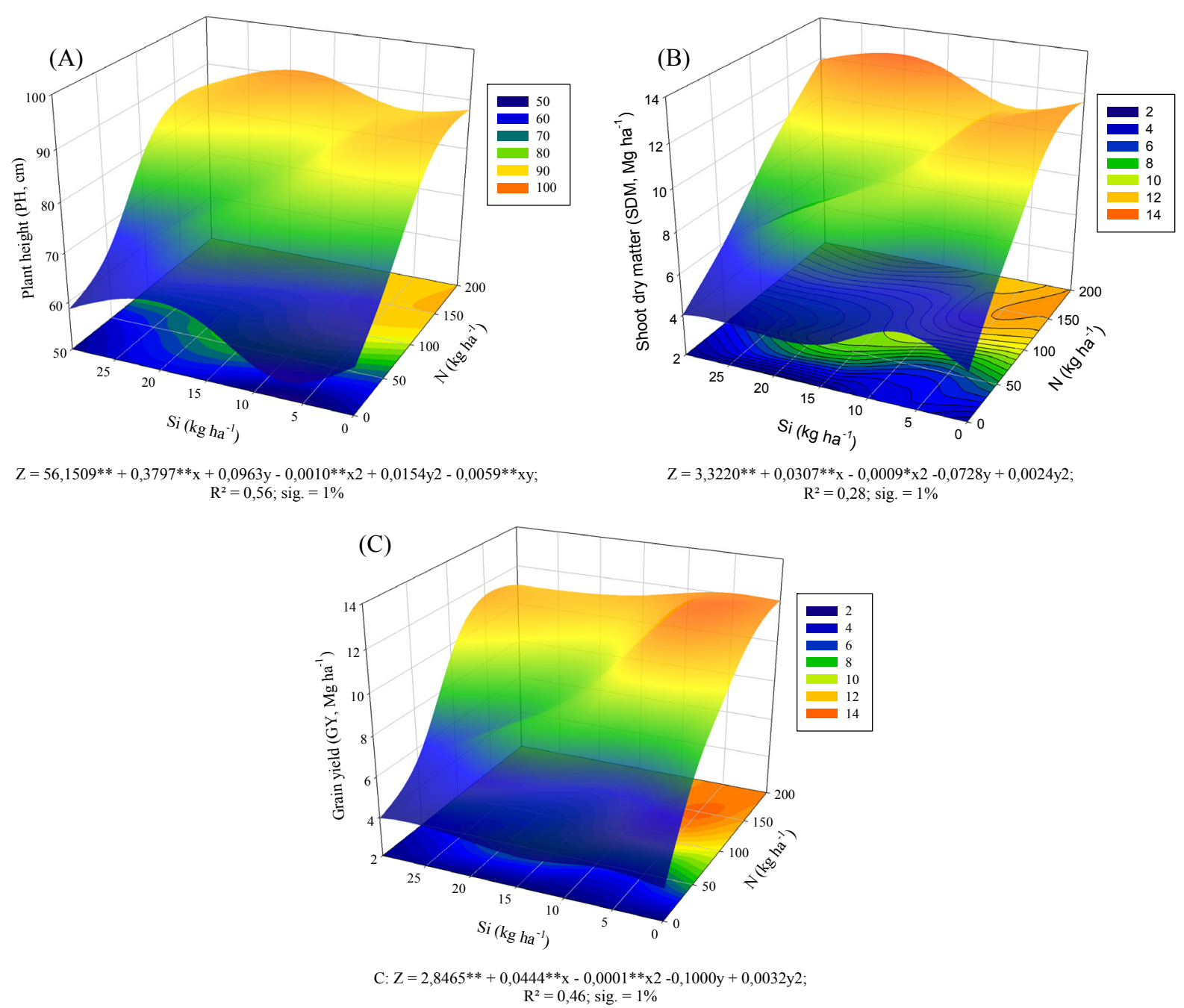

Figure 4. Plant height (PH) (A), shoot dry matter (SDM) (B) and grain yield (GY) (13\% b.u.) (C) as a function of increasing doses of nitrogen $(\mathrm{N})$ and silicon $(\mathrm{Si})$ in rice plants. * and ${ }^{* *}$, represent significance (sig.) at the $5 \%$ and $1 \%$ probability levels by the t-test, respectively

For PH the different doses of $\mathrm{N}$ provided quadratic behavior (Figure $5 \mathrm{~A}$ ). The optimal doses for this variable were $200 \mathrm{~kg} \mathrm{ha}^{-1}$ of $\mathrm{N}$ when there was no $\mathrm{Si}$ supply and when fertilized with $7.5 \mathrm{~kg} \mathrm{ha}^{-1}$ of $\mathrm{Si}$, which corresponded to the maximum height of plants around $88 \mathrm{~cm}$. When doses of 15 and $30 \mathrm{~kg} \mathrm{ha}^{-1}$ of Si were given, optimal $\mathrm{N}$ doses were $100 \mathrm{~kg} \mathrm{ha}^{-1}$ and the plant reached 78 and $81 \mathrm{~cm}$, respectively (Figure 5A). 
(A)

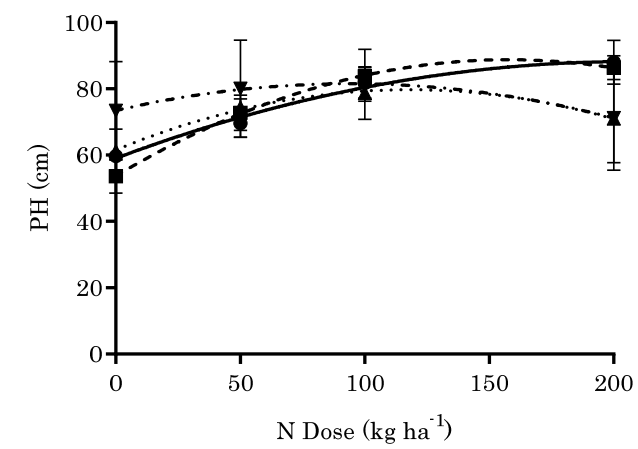

$\rightarrow 0 \mathrm{~kg} \mathrm{ha}{ }^{-1}$ of Si $\quad \mathrm{y}=59.05+0.2816 \mathrm{x}-0.0006 \mathrm{x}^{2} \mathrm{R}^{2}=0.85^{*}$

-匹- $7.5 \mathrm{~kg} \mathrm{ha}^{-1}$ of Si $\quad \mathrm{y}=53.78+0.4435 \mathrm{x}-0.0014 \mathrm{x}^{2} \mathrm{R}^{2}=0.92^{*}$

..4. $15 \mathrm{~kg} \mathrm{ha}^{-1}$ of Si $\mathrm{y}=61.6+0.3079 \mathrm{x}-0.0013 \mathrm{x}^{2} \mathrm{R}^{2}=0.42^{*}$

(C)

- $\mathbf{-}-30 \mathrm{~kg} \mathrm{ha}^{-1}$ of $\mathrm{Si} \quad \mathrm{y}=73.49+0.1721 \mathrm{x} \cdot 0.0009 \mathrm{x}^{2} \mathrm{R}^{2}=0.11^{\mathrm{ns}}$

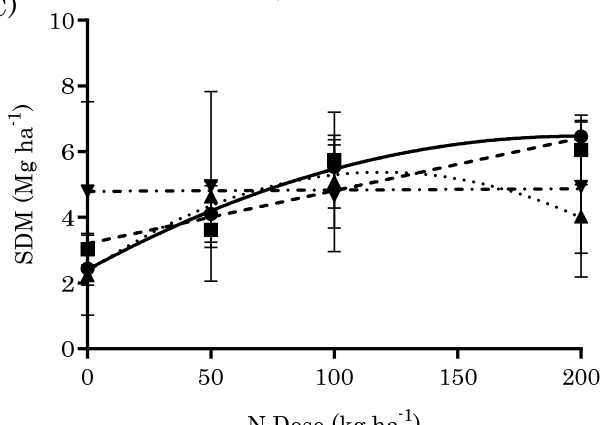

- $0 \mathrm{~kg} \mathrm{ha}{ }^{-1}$ of $\mathrm{Si} \mathrm{y}=2.48+0.0409 \mathrm{x}-0.0001 \mathrm{x}^{2} \mathrm{R}^{2}=0.88^{*}$

-匹- $7.5 \mathrm{~kg} \mathrm{ha}^{-1}$ of $\mathrm{Si} \quad \mathrm{y}=2.79+0.0329 \mathrm{x} \mathrm{R}^{2}=0.63 \mathrm{~ns}$

-4. $15 \mathrm{~kg} \mathrm{ha}^{-1}$ of Si $\mathrm{y}=2.35+0.0506 \mathrm{x} \cdot 0.0002 \mathrm{x}^{2} \mathrm{R}^{2}=0.45^{*}$

- $-30 \mathrm{~kg} \mathrm{ha}^{-1}$ of $\mathrm{Si} y=4.84 \cdot 0.0016 \mathrm{x} \mathrm{R}^{2}=0.0 \mathrm{~ns}$

(E)

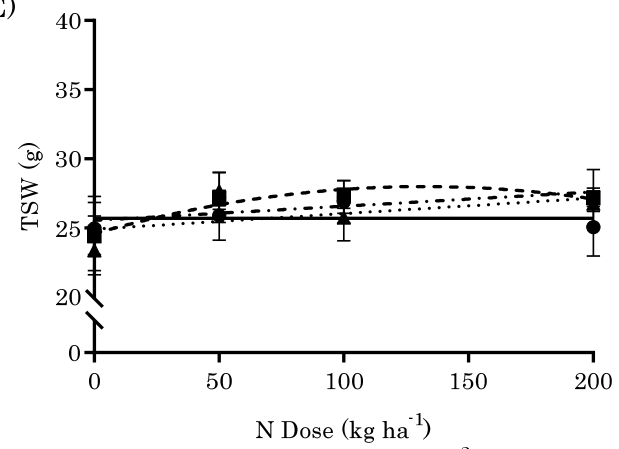

$\rightarrow 0 \mathrm{~kg} \mathrm{ha}{ }^{-1}$ of Si y $=24.84+0.0355 \mathrm{xR}^{2}=0.18 \mathrm{~ns}$

- $7.5 \mathrm{~kg} \mathrm{ha}{ }^{-1}$ of $\mathrm{Si} \quad \mathrm{y}=24.58+0.0515 \mathrm{x}-0.0001 \mathrm{x}^{2} \mathrm{R}^{2}=0.47$ *

..4 $15 \mathrm{~kg} \mathrm{ha}^{-1}$ of $\mathrm{Si} \quad \mathrm{y}=24.04+0.0473 \mathrm{x} \mathrm{R}^{2}=0.31 \mathrm{~ns}$

- $-30 \mathrm{~kg} \mathrm{ha}^{-1}$ of Si $\mathrm{y}=24.89+0.0375 \mathrm{xR}^{2}=0.27 \mathrm{~ns}$

Figure 5. Plant height (PH) (A) values, number of tillers (NT) (B), shoot dry matter (SDM) (C), grain yield (GY)

(D) and weight of one thousand seeds (TSW) (E) as a function of N and Si doses. Cultivar AN Cambará. $2014 / 2015$ crop year. $*$ and $* *$, represent significance at the $5 \%$ and $1 \%$ probability levels by the t-test. Campo Verde, MT, Brazil 2015
(B)

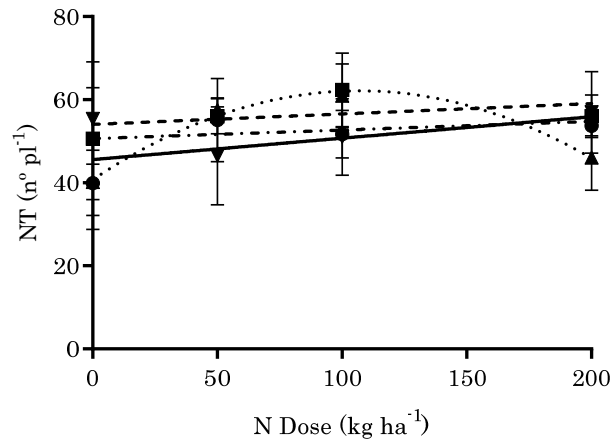

$0 \mathrm{~kg} \mathrm{ha}^{-1}$ of Si $\quad \mathrm{y}=41.67+0.2137 \mathrm{x} \mathrm{R} \mathrm{R}^{2}=0.31 \mathrm{~ns}$

-m. $7.5 \mathrm{~kg} \mathrm{ha}^{-1}$ of Si $\mathrm{y}=50.03+0.1922 \mathrm{x} \mathrm{R}^{2}=0.15 \mathrm{~ns}$

A. $15 \mathrm{~kg} \mathrm{ha}^{-1}$ of Si $\mathrm{y}=40.77+0.4001 \mathrm{x}-0.0018 \mathrm{x}^{2} \mathrm{R}^{2}=0.70^{* *}$

- $\mathbf{-} \quad 30 \mathrm{~kg} \mathrm{ha}^{-1}$ of Si $\quad \mathrm{y}=54.19 \cdot 0.1269 \times \mathrm{R}^{2}=0.14 \mathrm{~ns}$

(D)

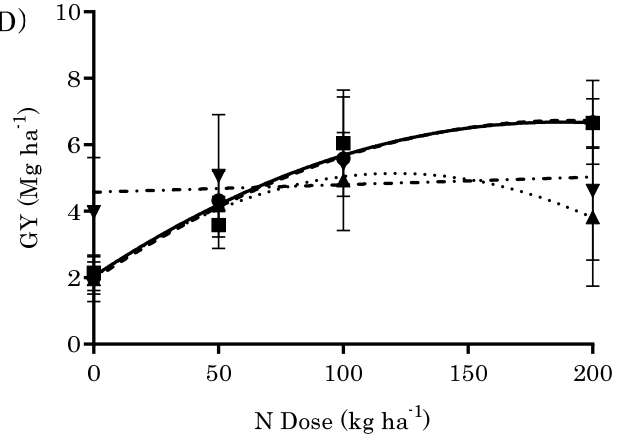

$\rightarrow 0 \mathrm{~kg} \mathrm{ha}{ }^{-1}$ of Si $\mathrm{y}=2.04+0.0496 \mathrm{x}-0.0001 \mathrm{x}^{2} \mathrm{R}^{2}=0.83^{*}$

- - $7,5 \mathrm{~kg} \mathrm{ha}{ }^{-1}$ of Si $\mathrm{y}=1.94+0.0500 \mathrm{x}-0.0001 \mathrm{x}^{2} \mathrm{R}^{2}=0.78^{*}$

-4. $15 \mathrm{~kg} \mathrm{ha}^{-1}$ of Si $\mathrm{y}=2.01+0.0516 \mathrm{x}-0.0002 \mathrm{x}^{2} \mathrm{R}^{2}=0.56^{*}$

- $\mathbf{-} \quad 30 \mathrm{~kg} \mathrm{ha}^{-1}$ of Si $\mathrm{y}=3.98+0.0263 \mathrm{x} \mathrm{R}^{2}=0.09 \mathrm{~ns}$ 
In relation to the number of tillers, there was no significant effect for $\mathrm{N}$ and $\mathrm{Si}$ doses, nor was there any interaction between them (Table 2, Figure 5B). It is inferred, therefore, that Si has no significant effect on the number of tillers in rice. However, increasing doses of $\mathrm{N}$ provided gradual increases in NT in quadratic form, thus evidencing the participation of $\mathrm{N}$ in the production of plant tissue (Ávila et al., 2010).

In relation to SDM, only $\mathrm{N}$ doses had a significant effect, and there was no influence of fertilization with $\mathrm{Si}$ in this parameter (Table 2, Figure 5C) and in this analysis, the increase in $\mathrm{N}$ doses alone increased SDM in a quadratic trajectory, as shown by the productivity of $5.6 \mathrm{Mg} \mathrm{ha}^{-1}$ of SDM at a dose of $137 \mathrm{~kg} \mathrm{ha}^{-1}$ of N.

Fertilization with $\mathrm{N}$ significantly affected rice yield (Table 2). In addition, there was a significant interaction between $\mathrm{N}$ and $\mathrm{Si}$ over this parameter, although the $\mathrm{Si}$, individually analyzed, did not provoke significant changes (Table 2). The highest productivity $\left(6.6 \mathrm{Mg} \mathrm{ha}^{-1}\right)$ was observed when $200 \mathrm{~kg} \mathrm{ha}^{-1}$ of $\mathrm{N}$ was applied and there was no application of Si (Figure 5D). In addition, with 7.5; 15 and $30 \mathrm{~kg} \mathrm{ha}^{-1}$ of Si, the yields obtained were $6.5 ; 4.9$ and $5.4 \mathrm{Mg} \mathrm{ha}^{-1}$, respectively.

The TSW was not influenced by Si, with only the influence of $\mathrm{N}$ (Table 2, Figure 5E). It was noted that the maximum value obtained for TSW $(27.0 \mathrm{~g})$ was observed when the applied $\mathrm{N}$ dose was $114.5 \mathrm{~kg} \mathrm{ha}^{-1}$ of N.

The different doses of $\mathrm{N}$ significantly influenced $(\mathrm{p}<0.05)$ the PGI and BGY (Table 3) (Figure 6). For Si, however, there was a significant effect on yield of broken grains (Table 3). Despite this, in general, it was observed that the higher the Si doses applied to the soil, the lower the values obtained for whole grain yield (Figure 7A).

Table 3. Analysis of variance of the yield of whole grains (WGY), broken grains yield (BGY), yield of grains benefited (YGB) and percentual yield of grains benefited (PYGB). Grow AN Cambará, harvest 2014/2015. Campo Verde, MT, Brazil 2015

\begin{tabular}{|c|c|c|c|c|}
\hline Treatment & WGY & BGY & YGB & PYGB \\
\hline & \multicolumn{3}{|c|}{ 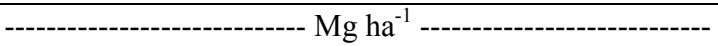 } & $\%$ \\
\hline Doses of $\mathrm{N}$ & $13.82 * *$ & $11.58 * *$ & $13.48 * *$ & $1.84^{\mathrm{ns}}$ \\
\hline Doses of Si & $3.17^{\mathrm{ns}}$ & $4.79 *$ & $3.51^{\mathrm{ns}}$ & $0.74^{\mathrm{ns}}$ \\
\hline $\mathrm{N} * \mathrm{Si}$ & $2.94 *$ & $2.44^{*}$ & $2.87 *$ & $0.20_{\mathrm{ns}}$ \\
\hline $\mathrm{CV}(\%)$ & 16.62 & 25.17 & 17.16 & 15.37 \\
\hline
\end{tabular}

Note. ${ }^{* *}, *$ and ns: significant at $1 \%, 5 \%$ and not significant, respectively, by the t-test.

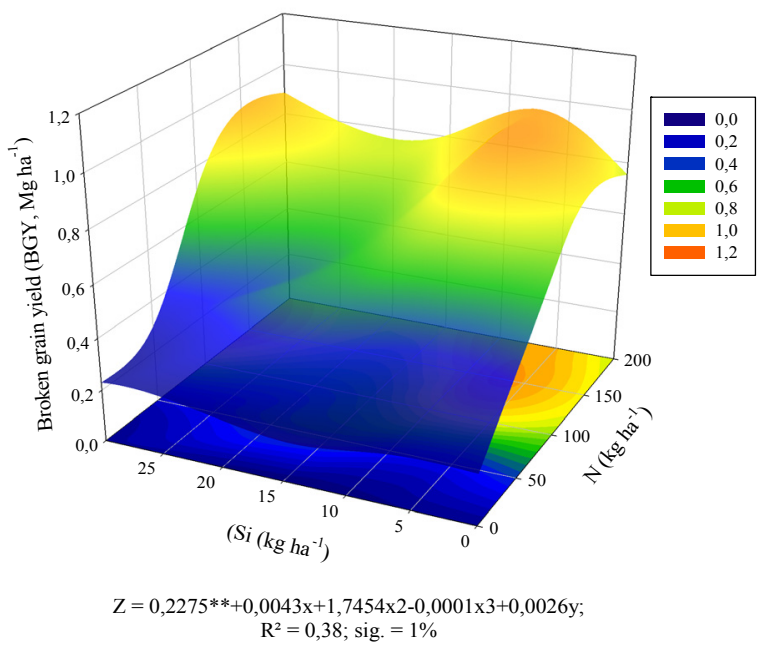

Figure 6. Broken grain yield (BGY) of rice plants as a function of the nitrogen $(\mathrm{N})$ and silicon $(\mathrm{Si})$ rates. * and **, represent significance (sig.) at the $5 \%$ and $1 \%$ probability levels by the t-test, respectively

The BGY, with the supply of $7.5 \mathrm{~kg} \mathrm{ha}^{-1}$ and $150 \mathrm{~kg} \mathrm{ha}^{-1}$ of $\mathrm{N}$, was observed a larger number of broken grains (Figures 6 and 7B). However, it was observed that from the addition of $15 \mathrm{~kg} \mathrm{ha}^{-1}$ of Si, there was a reduction in the number of broken grains, thus suggesting the efficacy of Si over this parameter. 
(A)

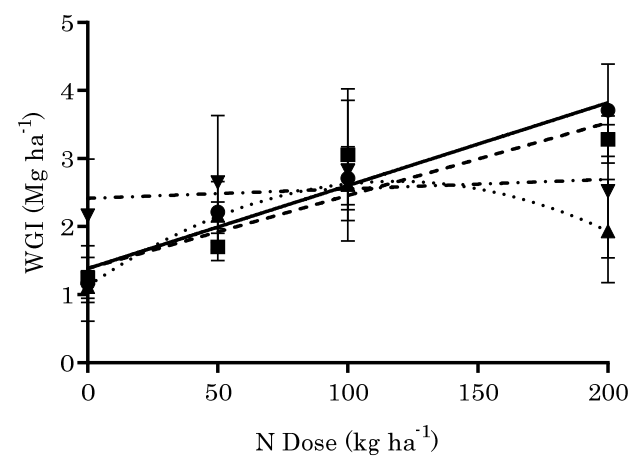

$0 \mathrm{~kg} \mathrm{ha}{ }^{-1}$ of Si y $=1.21+0.0194 \times \mathrm{R}^{2}=0.78 \mathrm{~ns}$

-匹 $7.5 \mathrm{~kg} \mathrm{ha}^{-1}$ of Si $\mathrm{y}=1.10+0.0222 \mathrm{x} \mathrm{R}^{2}=0.70 \mathrm{~ns}$

A. $15 \mathrm{~kg} \mathrm{ha}{ }^{-1}$ of Si $\mathrm{y}=1.12+0.0260 \mathrm{x} \cdot 0.0001 \mathrm{x}^{2} \mathrm{R}^{2}=0.67^{* *}$

- $\mathbf{-} 30 \mathrm{~kg} \mathrm{ha}^{-1}$ of Si $\mathrm{y}=2.16+0.0116 \mathrm{x} \mathrm{R}^{2}=0.07 \mathrm{~ns}$

(C)

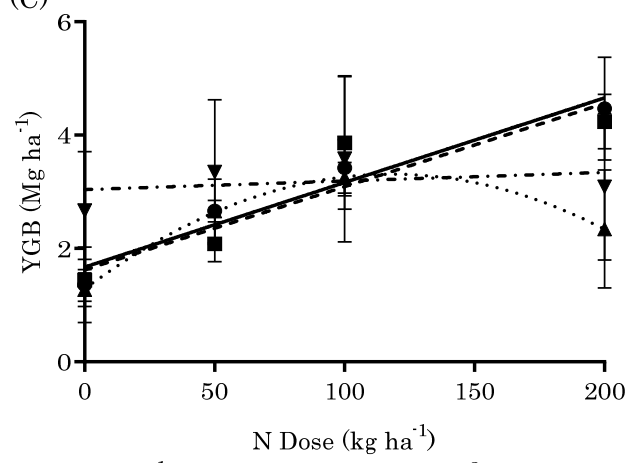

$\rightarrow 0 \mathrm{~kg} \mathrm{ha}{ }^{-1}$ of $\mathrm{Si} \quad \mathrm{y}=1.39+0.0265 \mathrm{xR}^{2}=0.78 \mathrm{~ns}$

-匹. $7.5 \mathrm{~kg} \mathrm{ha}^{-1}$ of Si $\mathrm{y}=1.25+0.0297 \mathrm{x} \mathrm{R}^{2}=0.74 \mathrm{~ns}$

-4. $15 \mathrm{~kg}$ ha ${ }^{-1}$ of Si $\mathrm{y}=1.2+0.0343 \mathrm{x}-0.0001 \mathrm{x}^{2} \mathrm{R}^{2}=0.68^{*}$

- $\mathbf{-} \quad 30 \mathrm{~kg} \mathrm{ha}^{-1}$ of Si $\mathrm{y}=2.6+0.0164 \mathrm{xR}^{2}=0.08 \mathrm{~ns}$
(B)

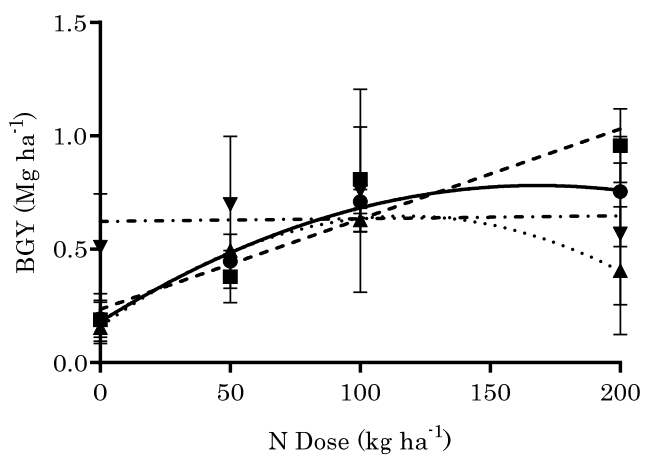

$\rightarrow 0 \mathrm{~kg} \mathrm{ha}{ }^{-1}$ of Si $\quad \mathrm{y}=0.18+0.0071 \mathrm{x}-0.00002 \mathrm{x}^{2} \mathrm{R}^{2}=0.74^{*}$

-匹. $7.5 \mathrm{~kg} \mathrm{ha}^{-1}$ of Si $\quad \mathrm{y}=0.15+0.0074 \mathrm{x} \mathrm{R}^{2}=0.79 \mathrm{~ns}$

.. $15 \mathrm{~kg} \mathrm{ha}{ }^{-1}$ of Si $\mathrm{y}=0.15+0.0083 \mathrm{x}-0.00003 \mathrm{x}^{2} \mathrm{R}^{2}=0.64^{* *}$

- $\mathbf{-} \quad 30 \mathrm{~kg} \mathrm{ha}^{-1}$ of $\mathrm{Si} \quad \mathrm{y}=0.51+0.0047 \mathrm{x} \mathrm{R}^{2}=0.10 \mathrm{~ns}$

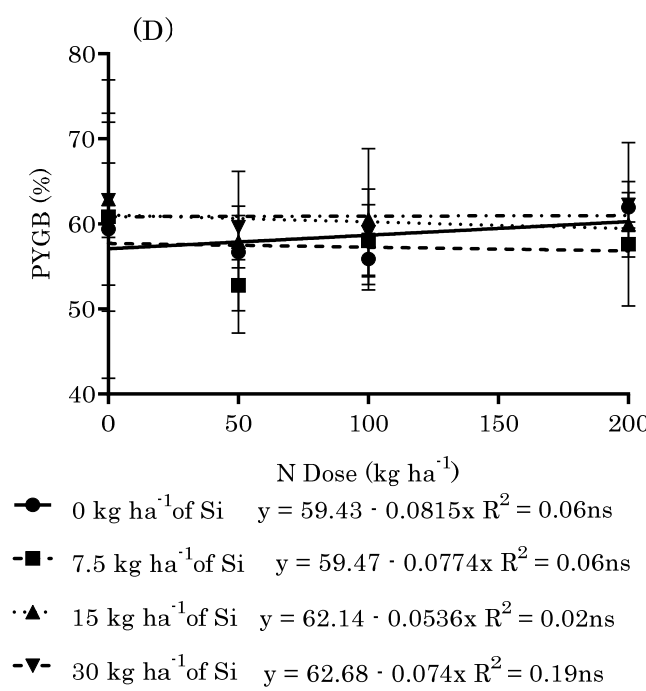

Figure 7. Yield of whole grains (WGY) (A), broken grains (BGY) (B), yield of grains benefited (YGB) (C) and percentage yield of grains benefited (PYGB) (D) as a function of N and Si doses. 2014/2015 crop year. * and **, represent significance at the 5\% and 1\% probability levels by the t-test in Campo Verde, MT, Brazil 2015

The PYGB showed increase as a function of the doses of $\mathrm{N}$ used, following a quadratic tendency (Table 3, Figure 7D). In this context, $4.4 \mathrm{Mg} \mathrm{ha}^{-1}$ of grains was observed after the treatment when there was no supply of $\mathrm{Si}$. In turn, in the adjustment of $7.5 ; 15$ and $30 \mathrm{~kg} \mathrm{ha}^{-1}$ of $\mathrm{Si}$, the YGB values were $4.2 ; 3.2$ and $3.5 \mathrm{Mg} \mathrm{ha}{ }^{-1}$, evidencing the reduction of this parameter with the increase of Si doses (Figure 7C).

\section{Discussion}

The significant influence of $\mathrm{N}$ and $\mathrm{Si}$, when individually analyzed, show that different doses of Si have influence on the chlorophyll content of the rice plant at 45 DAS. However, at 55, 65 and 85 DAS, the different Si doses indicated that Si may be of little importance as regards chlorophyll content at these periods (Figures 2A, 2B and 2C).

According to Sánchez et al. (2014), between 45 and 60 DAS, the rice plant is in the process of floral differentiation, while from 70 to $100 \mathrm{DAS}$, the plant is in full bloom. That is, the significant influence of Si doses at 45 DAS indicates that at this phenological stage $\mathrm{Si}$ acts as an important element in the increase of chlorophyll molecules. In addition, it suggests that evaluations aimed at quantifying the effect of $\mathrm{Si}$ on the photosynthetic process of rice plants should be performed at the beginning of the floral differentiation process (45 DAS), since, after that date, increases in Si doses do not cause increases proportions in the chlorophyll content of the leaves. 
Thus, these results corroborate the hypothesis that Si may increase the content of chlorophyll in the leaves of rice plants may favor the photosynthetic process (Epstein \& Bloom, 2006; Jeer et al., 2018). However, when $30 \mathrm{~kg}$ $\mathrm{ha}^{-1}$ of $\mathrm{Si}$ was applied, it was not possible to reach the maximum point of chlorophyll content, even with the application of $200 \mathrm{~kg} \mathrm{ha}^{-1}$ of $\mathrm{N}$ (Figure 3A) suggesting that the application of too much $\mathrm{Si}$ can attenuate the increase of the chlorophyll content in the rice leaves, and this phenomenon can also explain, among other factors, the reason for the lower incidence of sucking insects in the rice leaf when applied $\mathrm{Si}$, because according to Gomes et al. (2011), N fertilization in high doses, besides physiological disorders in the plant, increases the incidence of insect pests with sucking food habit due to the high activity of the sap flow. The increase in chlorophyll content by Si supply to plants was also observed by Emrich et al. (2011) in tomato.

It was possible to observe visually a certain difference in the architecture of the rice plants due to the Si doses. That is, through daily field experiment checks (unpublished data), it was possible to verify that the plants that received Si presented leaves that were more upright than those receiving only $\mathrm{N}$.

The explanation for this is that, according to Dersch et al. (2016), Si is accumulated in the epidermal cells of the aerial part, reducing the angle of opening of the leaves with the axis of the plant, making them stand erect, and this consequently decreases the auto shading and favors a greater interception of light and better photosynthetic efficiency.

The reduction of chlorophyll content in the leaf observed between the evaluations performed at 65 and 85 DAS (from 42.7 to 39.9) (Figures 3C and 3D) can be explained by the fact that the plant is, at the time of analysis, in phase of full flowering, that is, in an intense process of internal translocation of nutrients and, therefore, the $\mathrm{N}$ present in the leaves is being translocated and accumulated in the grains. Therefore, it is considered normal this slight reduction in the contents observed in the leaves demonstrated by the smaller values measured by the chlorophyll meter.

The highest plant height $(\mathrm{PH})$ and the consequent quadratic effect of increasing doses of $\mathrm{N}$ in the rice plant (Figure 5A) when there was no Si supply and when fertilized with $7.5 \mathrm{~kg} \mathrm{ha}^{-1} \mathrm{Si}(88 \mathrm{~cm}$ of height) is due to the fact that $\mathrm{N}$ is constituent of the structure of amino acids and structural proteins, enzymes and coenzymes (Zhao et al., 2015), and consequently has a function in several processes in the plant, among them cell multiplication and differentiation, with higher leaf area index and higher production of vegetative and reproductive buds (Malavolta, 2006; Sui et al., 2013).

In general, $\mathrm{N}$ provides greater development, leaf area index and plant height (Kichel et al., 2011; Passos et al., 2015). On the other hand, depending on the amount of $\mathrm{N}$ available, growth in height may favor lodging (Chen et al., 2018). In the present study there was no occurrence of lodging of plants in any of the treatments, even for the higher doses of $\mathrm{N}$.

In relation to the number of tillers (NT), when there was no significant effect on the interaction between $\mathrm{N}$ and $\mathrm{Si}$ doses (Table 2, Figure 5B), it is understood that Si does not have a significant effect in relation to the number of tillers in rice (Ávila et al., 2010). In addition, the increase of $\mathrm{N}$ rates, when applied in isolation, provided gradual increases in NT in quadratic form, thus evidencing the participation of $\mathrm{N}$ in the production of plant tissue.

According to Thakur et al. (2019) and Bianchet et al. (2015), the availability of nitrogen is one of the factors that most interfere on the emission of tiller in the plants of the family Poaceae. In addition, for rice, using the explanation of Ávila et al. (2010), Si only affects the diameter and stiffness of the main stem, increasing the transport of $\mathrm{O}_{2}$ to the rhizosphere, which facilitates the oxidation of $\mathrm{Fe}$ and $\mathrm{Mn}$ in excess, but does not influence the increase of tillering. Similar results were found by Fageria et al. (2011), who obtained an increase in the number of tillers caused by nitrogen fertilization, in both rainfed and irrigated irrigation.

The results obtained in terms of SDM (Table 2, Figure 5C) are in accordance with those found by Mauad et al. (2013) and Ávila et al. (2010), which, evaluating the influence of silicon content in the soil and upland rice plants, observed a significant effect only for the $\mathrm{N}$ rates on the accumulation of dry matter by the plant, with $\mathrm{Si}$ being therefore not significantly influenced the accumulation of SDM. In this sense, Epstein and Bloom (2006) reported that the increase in the production of SDM obtained by the increase of the nitrogen fertilization is due to the participation of this nutrient in the production of vegetal tissue, such as cell division and constitution of tissues.

In relation to that observed in relation to rice yield (Table 2, Figure 5D). Ávila et al. (2010), since these latter authors showed an increase of panicles per plant and, as a result, consequently, increase in productivity with the supply of $\mathrm{Si}$, that is, results divergent from those obtained by this work. 
However, the results observed here agree with Hernandes et al. (2010) and Lopes et al. (2013), which, however, verified that as the $\mathrm{N}$ doses increased, consequently the productivities increased, being the highest yields obtained when applied approximately $150 \mathrm{~kg} \mathrm{ha}^{-1}$ of N. In fact, Korndörfer et al. (1999) and Ning et al. (2017) consider that the effect of $\mathrm{Si}$ is more expressive on the control of diseases, pests and resistance to water stress and not always these beneficial effects are linked to grain yield.

The results obtained from TSW (Table 2, Figure 5E) are like the weight of one thousand seeds of 17 rice varieties evaluated by Passos et al. (2015) when the latter studied improved cultivars of rice in relation to the efficiency of the use of $\mathrm{N}$ in tropical floodplain soils.

In other words, the effect of $\mathrm{N}$ doses on vegetative growth, characterized by increased height, dry shoot mass and number of tillers, promoted a greater redistribution of photo assimilates to the panicles and consequently to the grains, resulting in an increase in the TSW, that is, evidencing that the increase of doses of N may promote increase in TSW (Wu et al., 2017; Ning et al., 2017).

The possible explanation for the results evidenced in Table 3 and Figure 6, specifically the fact that the higher the Si doses applied to the soil, the lower the values obtained of whole grain yield, is that the adequate availability of water, and not predominantly $\mathrm{Si}$, is the most relevant factor in increasing the percentage of whole grains in a rice batch (Guimarães et al., 2011).

The previous statement was certainly included in the analysis of the results of BGY, since with the supply of 7.5 $\mathrm{kg} \mathrm{ha}^{-1}$ and $150 \mathrm{~kg} \mathrm{ha}^{-1}$ of $\mathrm{N}$, a larger number of broken grains was observed (Figures 6 and 7B), however, it was also observed that from the addition of $15 \mathrm{~kg} \mathrm{ha}^{-1}$ of Si, there was a reduction in the number of broken grains, suggesting, consequently, an increase in the resistance of rice grains to the increase in the availability of Si to the rice plant.

In a similar work, Artigiani et al. (2012) did not observe effect of fertilization with Si on the yield of broken grains, although they noticed that the percentage of broken grains was higher under rainfed conditions, with the increase of $\mathrm{N}$ doses. In the same experiment, these authors observed increase linear in the percentage of broken grains when applied $100 \mathrm{~kg} \mathrm{ha}^{-1}$ of Si. Similar results were also obtained by Artigiani et al. (2012), which, also, did not observe influence of $\mathrm{Si}$ for this parameter, but, nevertheless, there was interaction between $\mathrm{Si}$ and $\mathrm{N}$.

The increase of the PYGB as a function of the doses of $\mathrm{N}$ used following a quadratic function (Table 3, Figure 7D) can be explained by the participation of $\mathrm{N}$ in the constitution of the proteins of the grains, which in adequate doses, provides higher yield in the processing (Zhao et al., 2015). These results resemble those found by Fidelis et al. (2012), where increasing $\mathrm{N}$ doses increased the amount of grains benefited. Likewise, for this fact, the addition of $\mathrm{Si}$ in the plantation provided a smaller quantity of grains after processing, suggesting that $\mathrm{Si}$ is a factor of little influence for this variable. In this context, $4.4 \mathrm{Mg} \mathrm{ha}^{-1}$ of grains were observed after the treatment when there was no supply of Si. In turn, in the adjustment of 7.5; 15 and $30 \mathrm{~kg} \mathrm{ha}^{-1}$ of Si, the YGB values were 4.2; 3.2 and $3.5 \mathrm{Mg} \mathrm{ha}^{-1}$, evidencing the reduction of this parameter with the increase of Si doses (Figure 7C).

The PYGB was not affected by nitrogen fertilization or by the Si supply (Table 3). In other words, fertilization with $\mathrm{N}$ did not increase the yield of grains benefited despite the rice extracting large amount of this nutrient (Figure 7D). This is due to the high amount of nutrient available in the soil and the quality of the beneficiation process carried out on the samples. These results suggest that the beneficiation may be the primary cause of adequate nutrition and high-quality grain crops being undesirable after the processing, as consumers prefer the grains with good appearance and organoleptic and cooking quality (Sandhu et al., 2018).

Based on the results obtained, it was possible to infer that the use of increasing doses of silicon did not provide increases in most of the production components and, consequently, in the productivity and the opposite occurred with the N. However, in the rainfed system, to pay special attention to the application of higher doses of nitrogen, because this practice, despite increasing productivity, increases the cost of production and does not often translate into increased productivity or improved grain quality. The use of silicate fertilization did not increase productivity and grain quality. That is, although the rice absorbs a large amount of this nutrient, probably the amount in the soils of the rainfed region, where the study was implemented, is sufficient to supply the needs of the plant, and there is no need for further increases, unless the objective of reducing the incidence of insect pests by increasing the resistance caused by the layer of amorphous silica in the plant structures of the plant.

The results of this work are in agreement with those observed by other authors who also reported a lack of response to the application of silicon, even at doses well above the one used in the present study and in different regions of those of implantation of this present work, as reported by Mauad et al. (2013), which used doses of $0-560 \mathrm{~kg} \mathrm{ha}^{-1}$ of $\mathrm{Si}$. 


\section{Conclusions}

That $\mathrm{Si}$ affects the chlorophyll content, especially at $45 \mathrm{DAS}$, however, $\mathrm{N}$ is rather responsible for the chlorophyll content in the rice leaves. In addition, increasing application of Si does not significantly alter plant height, number of tillers, weight of one thousand seeds, grain yield and total grain yield, despite that, as shown by the results, Si doses above $15 \mathrm{~kg} \mathrm{ha}^{-1}$ provide a reduction in the yield of broken grains in rice, which may reduce the percentage of grain breakage during processing.

\section{Acknowledgements}

We thank the financial support of the National Council for Scientific and Technological Development and also the technical support of the Federal Institute of Education, Science and Technology of the State of Mato Grosso, Campo Verde Advanced Campus.

\section{References}

Artigiani, A. C. C. A., Crusciol, C. A. C., Arf, O., Alvarez, R. D. C. F., \& Nascente, A. S. (2012). Produtividade e qualidade industrial do arroz de terras altas em função da disponibilidade hídrica e adubação. Pesquisa Agropecuária Tropical, 42, 340-349. https://doi.org/10.1590/S1983-40632012000300011

Ávila, F. W., Baliza, D. P., Faquin, V., Araújo, J. L., \& Ramos, S. J. (2010). Silicon-nitrogen interaction in rice cultivated under nutrient solution. Revista Ciência Agronômica, 41, 184-190. https://doi.org/10.1590/ s1806-66902010000200003

Bianchet, P., Sangoi, L., Souza, C. A. D., Klauberg Filho, O., \& Panison, F. (2015). Desenvolvimento vegetativo do arroz irrigado afetado pela inoculação com Azospirillum e aplicação de nitrogênio mineral. Revista de la Facultad de Agronomía, 114, 201-207.

Cazetta, D. A., Arf, O., Buzetti, S., Sá, M. E. D., \& Rodrigues, R. A. F. (2008). Performance of upland rice to the nitrogen rates after different cover crops in no-till system. Bragantia, 67, 471-479. https://doi.org/10.1590/ S0006-87052008000200023

Chen, X., Wang, J., Wang, Z., Li, W., Wang, C., Yan, S., ... Wei, M. (2018). Optimized nitrogen fertilizer application mode increased culms lignin accumulation and lodging resistance in culms of winter wheat. Field Crops Research, 228, 31-38. https://doi.org/10.1016/j.fcr.2018.08.019

Dersch, L. M., Beckers, V., Rasch, D., Melzer, G., Bolten, C. J., Kiep, K., \& Wittmann, C. (2016). High-throughput plant metabolic profiling by stable isotope labelling and combustion isotope ratio mass spectrometry: In vivo assimilation and molecular re-allocation of carbon and nitrogen in rice. Plant Physiology, 171, 25-41. https://doi.org/10.1104/pp.15.01217

Emrich, E. B., Souza, R. J. D., Lima, A. A. D., Figueiredo, F. C., \& Silva, D. R. G. (2011). Cultivation of tomato in organic substrates under leaf spraying of potassium silicate in protected environment. Ciência e Agrotecnologia, 35, 56-61. https://doi.org/10.1590/S1413-70542011000100006

Epstein, E., \& Bloom, A. J. (2006). Nutrição mineral de plantas: Princípios e Perspectivas. Editora Planta, Londrina, Brasil.

Fageria, N. K., Moreira, A., \& Coelho, A. M. (2011). Yield and yield components of upland rice as influenced by nitrogen sources. Journal of Plant Nutrition, 34, 361-370. https://doi.org/10.1080/01904167.2011.536878

Fidelis, R. R., Rodrigues, A. M., Silva, G. F., Barros, H. B., Pinto, L. C., \& Aguiar, R. W. S. (2012). Eficiência do uso de nitrogênio em genótipos de arroz de terras altas. Pesquisa Agropecuária Tropical, 42, 124-128. https://doi.org/10.1590/s1983-40632012000100018

Gmach, M. R., Dias, B. O., Silva, C. A., Nóbrega, J. C., Lustosa-Filho, J. F., \& Siqueira-Neto, M. (2018). Soil organic matter dynamics and land-use change on Oxisols in the Cerrado, Brazil. Geoderma Regional, 14, e00178. https://doi.org/10.1016/j.geodrs.2018.e00178

Gomes, C. F., Marchetti, M. E., Novelino, J. O., Mauad, M., \& Alovisi, A. M. T. (2011). Disponibilidade de silício para a cultura do arroz, em função de fontes, tempo de incubação e classes de solo. Pesquisa Agropecuária Tropical, 41, 10-15. https://doi.org/10.5216/pat.v41i4.10906

Guimarães, C. M., Stone, L. F., Oliveira, J. P. D., Rangel, P. H. N., \& Rodrigues, C. A. P. (2011). Sistema radicular do arroz de terras altas sob deficiência hídrica. Pesquisa Agropecuária Tropical, 41, 126-134. https://doi.org/10.5216/pat.v41i1.8460 
Hernandes, A., Buzetti, S., Andreotti, M., Arf, O., \& Sá, M. E. D. (2010). Doses, sources and periods of nitrogen application in rice cultivars. Ciência e Agrotecnologia, 34, 307-312. https://doi.org/10.1590/s1413-7054201 0000200006

Jeer, M., Suman, K., Maheswari, T. U., Voleti, S. R., \& Padmakumari, A. P. (2018). Rice husk ash and imidazole application enhances silicon availability to rice plants and reduces yellow stem borer damage. Field Crops Research, 224, 60-66. https://doi.org/10.1016/j.fcr.2018.05.002

Kichel, E., Fidelis, R. R., Santos, M. M., Brandão, D. R., Cancellier, E. L., \& Nascimento, I. R. (2011). Nitrogen in lowland rice genotypes in Tocantins State, Brazil. Revista Ceres, 58, 84-89. https://doi.org/ 10.1590/s0034-737x2011000100013

Korndörfer, G. H., Coelho, N. M., Snyder, G. H., \& Mizutani, C. T. (1999). Evaluation of soil extractants for silicon availability in upland rice. Revista Brasileira de Ciência do Solo, 23, 101-106. https://doi.org/ 10.1590/s0100-06831999000100013

Lopes, M. B. S., Sousa, S. A., Nascimento, I. R., \& Fidelis, R. R. (2013). Resposta de cultivares de arroz à adubação nitrogenada em solos arenosos de várzea tropical. Revista Verde de Agroecologia e Desenvolvimento Sustentável, 8, 86-92.

Malavolta, E. (2006). Manual de nutrição mineral de plantas. Agronômica Ceres, São Paulo, Brasil.

Marchezan, E., Villa, S. C. C., Marzari, V., Korndorfer, G. H., \& Santos, F. M. (2004). Aplicação de silício em arroz irrigado: efeito nos componentes da produção. Bioscience Journal, 20, 125-131.

Marxen, A., Klotzbücher, T., Jahn, R., Kaiser, K., Nguyen, V. S., Schmidt, A., ... Vetterlein, D. (2016). Interaction between silicon cycling and straw decomposition in a silicon deficient rice production system. Plant and Soil, 398(1-2), 153-163. https://doi.org/10.1007/s11104-015-2645-8

Mauad, M., Crusciol, C. A. C., Grassi Filho, H., \& Machado, S. R. (2013). Silica deposition and rate the nitrogen is silicon in rice. Semina: Ciências Agrárias, 34, 1653-1662. https://doi.org/10.5433/1679-0359.2013 v34n4p1653

Mo, Z., Lei, S., Ashraf, U., Khan, I., Li, Y., Pan, S., ... Tang, X. (2017). Silicon fertilization modulates 2-acetyl-1-pyrroline content, yield formation and grain quality of aromatic rice. Journal of Cereal Science, 75, 17-24. https://doi.org/10.1016/j.jcs.2017.03.014

Ning, C., Qu, J., He, L., Yang, R., Chen, Q., Luo, S., \& Cai, K. (2017). Improvement of yield, pest control and Si nutrition of rice by rice-water spinach intercropping. Field Crops Research, 208, 34-43. https://doi.org/ 10.1016/j.fcr.2017.04.005

Passos, N. G., Sousa, S. A., Lopes, M. B. S., Varavallo, M. A., Oliveira, T. C., \& Fidelis, R. R. (2015). Nitrogen use efficiency in rice genotypes in tropical lowland soils of the State of Tocantins, Brazil. Agro@mbiente, 9, $8-16$.

Paula, M. B., Filho, M. B., \& Carvalho, J. G. (1999). Arroz de sequeiro. In A. C. Ribeiro, P. T. G. Guimaraes, \& V. H. Alvarez (Eds.), Recomendações para o uso de corretivos e fertilizantes em Minas Gerais. CFSEMG, Viçosa, Brazil.

R Core Team. (2015). R: A language and environment for statistical computing. R Foundation for Statistical Computing, Vienna, Austria. Retrieved from http://www.R-project.org

Sánchez, B., Rasmussen, A., \& Porter, J. R. (2014). Temperatures and the growth and development of maize and rice: A review. Global Change Biology, 20, 408-417. https://doi.org/10.1111/gcb.12389

Sandhu, R. S., Singh, N., Kaler, R. S. S., Kaur, A., \& Shevkani, K. (2018). Effect of degree of milling on physicochemical, structural, pasting and cooking properties of short and long grain Indica rice cultivars. Food Chemistry, 260, 231-238. https://doi.org/10.1016/j.foodchem.2018.03.092

Seebold, K. W., Datnoff, L. E., Correa-Victoria, F. J., Kucharek, T. A., \& Snyder, G. H. (2004). Effects of silicon and fungicides on the control of leaf and neck blast in upland rice. Plant Disease, 88, 253-258. https://doi.org/10.1094/PDIS.2004.88.3.253

Sui, B., Feng, X., Tian, G., Hu, X., Shen, Q., \& Guo, S. (2013). Optimizing nitrogen supply increases rice yield and nitrogen use efficiency by regulating yield formation factors. Field Crops Research, 150, 99-107. https://doi.org/10.1016/j.fcr.2013.06.012 
Sun, Y., Mi, W., Su, L., Shan, Y., \& Wu, L. (2019). Controlled-release fertilizer enhances rice grain yield and N recovery efficiency in continuous non-flooding plastic film mulching cultivation system. Field Crops Research, 231, 122-129. https://doi.org/10.1016/j.fcr.2018.11.013

Thakur, A. K., Mandal, K. G., \& Raychaudhuri, S. (2019). Impact of crop and nutrient management on crop growth and yield, nutrient uptake and content in rice. Paddy and Water Environment, 18, 1-13. https://doi.org/10.1007/s10333-019-00770-x

Wu, M., Liu, M., Liu, J., Li, W. T., Jiang, C. Y., \& Li, Z. P. (2017). Optimize nitrogen fertilization location in root-growing zone to increase grain yield and nitrogen use efficiency of transplanted rice in subtropical China. Journal of Integrative Agriculture, 16(9), 2073-2081. https://doi.org/10.1016/s2095-3119(16) 61544-7

Yoneyama, T., Tanno, F., Tatsumi, J., \& Mae, T. (2016). Whole-plant dynamic system of nitrogen use for vegetative growth and grain filling in rice plants (Oryza sativa L.) as revealed through the production of 350 grains from a germinated seed over 150 days: a review and synthesis. Frontiers in Plant Science, 7 , 1151-1177. https://doi.org/10.3389/fpls.2016.01151

Zhao, Y., Xi, M., Zhang, X., Lin, Z., Ding, C., Tang, S., ... Ding, Y. (2015). Nitrogen effect on amino acid composition in leaf and grain of japonica rice during grain filling stage. Journal of Cereal Science, 64, 29-33. https://doi.org/10.1016/j.jcs.2015.03.011

\section{Abbreviations}

b.u.: moisture calculated on a wet basis;

BGY: broken grain yield;

DAS: days after sowing;

GY: grain yield;

i.a. $\mathrm{ha}^{-1}$ : active ingredient per hectare;

NPK 0-25-15: formulation in mixture of nitrogen- $\mathrm{NH}_{2}$-phosphorus- $\mathrm{P}_{2} \mathrm{O}_{5}$-potassium- $\mathrm{KCl}$, in percentage terms contained in the formulation;

NT: number of tillers;

PH: plant height;

PYGB: percentage yield of grains benefited;

RTNP: Relative Total Neutralization Power;

SDM: shoot dry matter;

SPAD 502: portable chlorophyll meter, Model 502 from Minolta $^{\circledR}$;

TGY: total grain yield;

TSW: weight of one thousand seeds;

US: unit of measurement provided by portable chlorophyll meter;

WGY: whole grain yield;

YGB: yield of grains benefited.

\section{Copyrights}

Copyright for this article is retained by the author(s), with first publication rights granted to the journal.

This is an open-access article distributed under the terms and conditions of the Creative Commons Attribution license (http://creativecommons.org/licenses/by/4.0/). 